\title{
METODY ZWIĘKSZANIA WŁAŚCIWOŚCI WYTRZYMALOŚCIOWYCH ZBROJONYCH BELEK BETONOWYCH
}

\begin{abstract}
Streszczenie: W rozdziale poddano analizie metody wzmacniania betonowych belek zginanych oraz rodzaje stosowanego zbrojenia głównego. Omówiono rodzaje materiałów kompozytowych wykorzystywanych $w$ budownictwie do wzmacniania i zbrojenia konstrukcji betonowych. Przedstawiono i porównano parametry oraz właściwości wytrzymałościowe tradycyjnego zbrojenia stalowego $\mathrm{z}$ nowoczesnymi prętami kompozytowymi FRP stosowanymi do zbrojenia belek betonowych. Ponadto scharakteryzowano najczęstsze przyczyny występowania awarii obiektów budowlanych i inżynierskich, a także streszczono tradycyjne metody wzmocnień żelbetowych elementów konstrukcyjnych. Dodatkowo zaprezentowano alternatywne, bardziej efektywne metody wzmocnień betonowych konstrukcji budowlanych z wykorzystaniem materiałów kompozytowych zbrojonych włóknami polimerowymi w tym również wzmocnień kompozytami wstępnie sprężonymi.
\end{abstract}

Słowa kluczowe: wytrzymałość, żelbet, kompozyty FRP, wzmocnienie, sprężenie

\section{Wprowadzenie}

Fundamentalnym wymogiem stawianym obiektom budowlanym i inżynierskim jest zapewnienie niezawodności oraz bezpieczeństwa zarówno w czasie ich realizacji jak i użytkowania. Niezawodność i bezpieczeństwo są określone w zależności od funkcji jaką obiekt ma spełniać oraz od miejsca w którym ma zostać zrealizowany. Zgodnie z teorią stanów granicznych w czasie założonego okresu użytkowania obiektu w zależności od określonych warunków eksploatacji niedopuszczalne jest przekro-

1 mgr inż., Wydział Budownictwa, Politechniki Częstochowskiej, e-mail: brozda.kinga@gmail.com.

2 dr hab. inż. Prof. PCz, Wydział Budownictwa, Politechniki Częstochowskiej, e-mail: jaceksel@poczta.onet.pl. 
czenie stanów granicznych nośności lub zniszczenia (ULS - ultimate limit states) oraz stanów granicznych użytkowalności (SLS - serviceability limit states) (RUNKIEWICZ L. 1999).

Dążąc do spełnienia stanów granicznych stosuje się szereg zabiegów mających na celu podniesienie parametrów wytrzymałościowych konstrukcyjnych elementów obiektów budowlanych. Już na etapie projektowania rozważane są odpowiednie rozwiązania konstrukcyjno - materiałowe ograniczające wielkość ciężaru własnego konstrukcji przy jednoczesnym zachowaniu lub nawet zwiększeniu parametrów jej dopuszczalnego obciążenia (nośności). Niestety wskutek błędów popełnianych nie tylko na etapie projektowania czy realizacji, ale również niewłaściwego użytkowania obiektów budowlanych może dojść do zużycia lub uszkodzenia zarówno poszczególnych elementów konstrukcyjnych jak i całej konstrukcji. Wówczas stosowane są różnego rodzaju metody przywrócenia utraconych wartości parametrów wytrzymałościowych, a nawet podniesienia nośności w stosunku do pierwotnej wartości (BASZKIEWICZ K., SELEJDAK J. 2014), (URBAN T. 2015).

\section{Zbrojenie elementów konstrukcyjnych}

Jednym z najbardziej znanych sposobów wzmocnienia betonowych elementów konstrukcyjnych jest stosowanie zbrojenia w postaci prętów stalowych. W ten sposób uzyskany materiał kompozytowy (żelbet), składający się z betonu i określonego stopnia zbrojenia stalowego (przeważnie 1-2\% pola przekroju poprzecznego zbrojonego elementu), łączy w sobie zalety obu tych materiałów. Beton w żelbecie pracuje na ściskanie, zaś stal na rozciąganie, a współpraca tych dwóch materiałów pozwala na właściwe wykorzystanie obu cech wytrzymałościowych (MADAJ A., WOŁOWSKI W. 2002).

W konstrukcjach żelbetowych zbrojenie określone jest mianem zbrojenia biernego, zatem współpraca praca pomiędzy stalą zbrojeniową a betonem rozpoczyna się $\mathrm{w}$ momencie, gdy dany element poddawany 
jest deformacjom wskutek działania obciążeń zewnętrznych lub wewnętrznych (takich jak m.in. skurcz betonu). Projektowanie elementów żelbetowych polega na wyznaczeniu niezbędnej ilości stali zbrojeniowej oraz rozstawu prętów tak, aby zapewnić pełną oraz efektywną współpracę obu materiałów (BASZKIEWICZ K., SELEJDAK J. 2014). Mimo wielu korzyści wynikających z połączenia betonu ze stalą, jednym z największych ograniczeń tradycyjnego żelbetu jest bardzo niska odporność stali zbrojeniowej na działanie czynników korozjotwórczych, co staje się kłopotliwe w chwili zarysowania elementu. Odporność konstrukcji żelbetowych na pracę w środowisku agresywnym jest dość niska. W związku z tym działanie czynników agresywnych takich jak m.in. długotrwałe zawilgocenie czy działanie soli odladzających, cykliczna zmiana temperatur lub duża zmienność obciążeń zewnętrznych, mogą prowadzić do uszkodzenia powierzchni betonu, a następnie do korozji stali zbrojeniowej (SELEJDAK J., BRÓZDA K. 2016).

Alternatywnym rozwiązaniem dla stosowania tradycyjnego zbrojenia stalowego, rozwiązującym problemy wynikające m.in. z korozji, są niemetaliczne pręty kompozytowe o osnowie polimerowej. W budownictwie wykorzystywane są najczęściej kompozyty zbrojone włóknami z uwagi na największą efektywność pod względem właściwości wytrzymałościowych i mechanicznych. W zależności od wykorzystanego podczas procesu produkcyjnego surowca, rozróżniane są cztery podstawowe rodzaje polimerowych wyrobów kompozytowych tj. zbrojonych włóknem (BASZKIEWICZ K., SELEJDAK J. 2015):

- szklanym GFRP - Glass Fiber Reinforced Polymers,

- węglowym CFRP - Carbon Fiber Reinforced Polymers,

- aramidowym AFRP - Aramid Fiber Reinforced Polymers,

- bazaltowym BFRP - Basalt Fiber Reinforced Polymer.

Cechą charakterystyczną kompozytowych prętów jest wysoki stosunek wytrzymałości do ciężaru własnego. Ciężar własny prętów z włókna szklanego jest znacznie mniejszy w porównaniu do stalowych prętów zbrojeniowych (rys. 1.), natomiast w przypadku wytrzymałości na rozciąganie wyrażonej $\mathrm{w} \mathrm{kN}$ jest odwrotnie (rys. 2.) - kompozytowe 
pręty zbrojeniowe mogą przenieść dużo większą wartość siły rozciągającej przy mniejszej średnicy pręta. Dzięki zastosowanej metodzie produkcji kompozytowych prętów (tj. odpowiedniego zespolenia ze sobą żywicznej matrycy ze włóknami zbrojeniowymi) możliwe jest uzyskanie właściwych parametrów wytrzymałościowych materiału. W procesie produkcyjnym prętów kompozytowych wykorzystuje się metodę pultruzji tj. prasowania ciągłego. Metoda ta polega na przeciąganiu włókien o wysokich właściwościach wytrzymałościowych przez zamkniętą komorę, celem zaimpregnowania ich syntetyczną żywicą, najczęściej winyloestrową. Dzięki takiemu rozwiązaniu zapewniona jest szczelność dyfuzyjna włókien, co prowadzi do wydłużenia trwałości gotowych wyrobów o co najmniej 50 lat, przy czym spadek wytrzymałości po tym czasie nie wynosi więcej niż $20 \%$ wartości pierwotnej wytrzymałości (SELEJDAK J., BRÓZDA K. 2016).

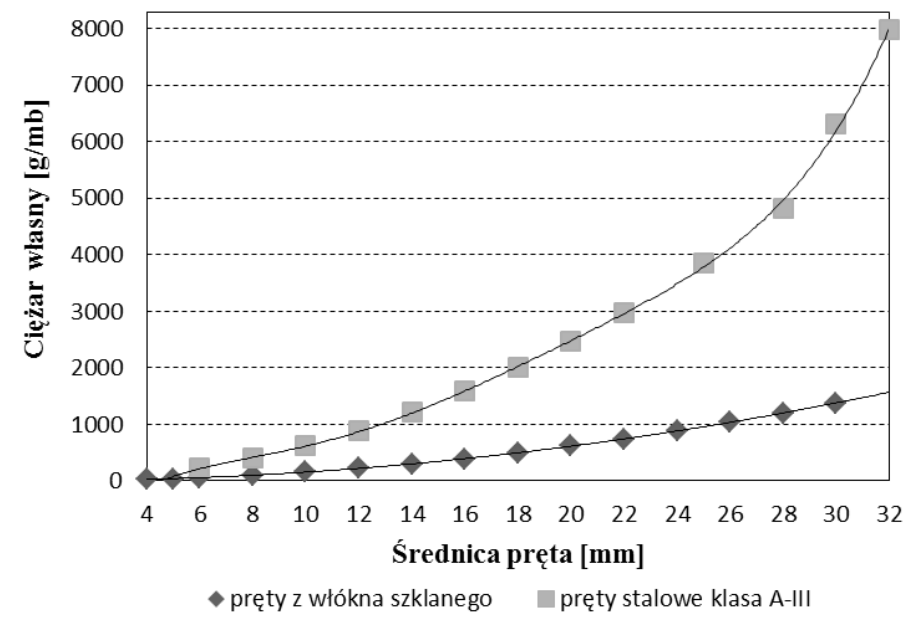

Rys. 1. Zależność ciężaru wlasnego wybranych prętów zbrojeniowych od wielkości średnicy

Źródło: materiały promocyjne dostępne na: http://polprek.pl/z dn. 03.01.2016 


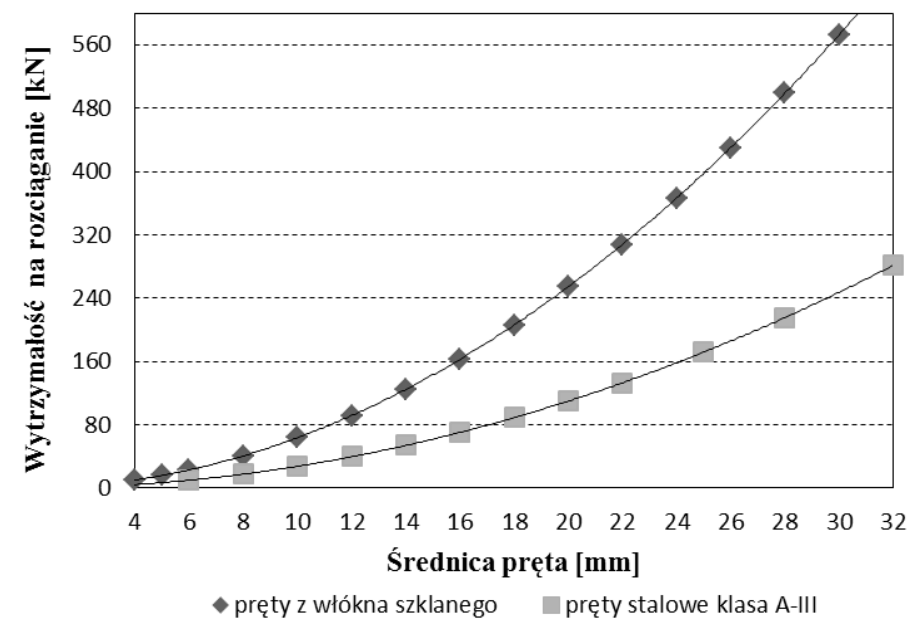

Rys. 2. Zależność sity rozciagającej możliwej do przeniesienia przez wybrane pręty zbrojeniowe od wielkości średnicy

Źródto: materiaty promocyjne dostępne na: http://polprek.pl/z dn. 03.01.2016

\section{Wzmocnienia istniejących konstrukcji}

W wyniku zużycia lub uszkodzenia elementów konstrukcyjnych, ale również zmiany funkcji użytkowych obiektów budowlanych możliwa jest utrata pierwotnych parametrów wytrzymałościowych oraz użytkowych. W związku z tym pojawia się konieczność dopasowania właściwości wytrzymałościowych elementów konstrukcyjnych poprzez zwiększenie pierwotnej nośności bądź sztywności, czy przywrócenia właściwości wytrzymałościowych równych co najmniej wartościom początkowym (BASZKIEWICZ K., SELEJDAK J. 2015).

Problematyka związana ze wzmacnianiem konstrukcji budowlanych jest istotnym aspektem działalności inżynierskiej. Zwykle jest wynikiem wcześniej zrealizowanej diagnostyki konstrukcji związanej m.in. $\mathrm{z}$ okresowo przeprowadzanym przeglądem technicznym przy uwzględnieniu obowiązujących wymagań Prawa budowlanego. Potrzeba 
przeprowadzenia wzmocnienia może wynikać ze stwierdzenia uszkodzeń konstrukcji lub elementów konstrukcyjnych (diagnostyka doraźna), a także $\mathrm{z}$ oceny potencjału oraz warunków przeprowadzania planowanych zmian konstrukcyjno-budowlanych w wyniku np. rozbudowy, nadbudowy oraz innych zmian technologiczno-użytkowych w obiekcie budowlanym (diagnostyka docelowa). Według badań statystycznych wykonanych na podstawie dotychczasowych awarii obiektów budowlanych wykazano, że około $40 \%$ stanowią awarie powstałe w wyniku błędnego użytkowania obiektów. Popełnione błędy wykonawcze stanowią następne $35 \%$ zaistniałych awarii, z kolei błędy projektowe - około 25\%. Do głównych przyczyn, które wymuszają konieczność wykonania wzmocnienia konstrukcji obiektów budowlanych i inżynierskich, oprócz popełnionych błędów projektowych oraz wykonawczych, należą (KAŁUŻA M., BARTOSIK T. 2015), (URBAN T. 2015):

- zwiększenie dopuszczalnych obciążeń poprzez np. zmianę sposobu użytkowania obiektu,

- konieczność redukcji zarysowań oraz ugięć elementów konstrukcyjnych (poprawa warunków stanu granicznego użytkowania),

- wprowadzenie zmian w schemacie statycznym istniejącej konstrukcji lub też wykonanie dodatkowych otworów w danym elemencie konstrukcyjnym,

- naprawa uszkodzeń konstrukcji powstałych w skutek przemieszczeń podłoża wywołanych m.in. nierównomiernym osiadaniem obiektu czy wstrząsami sejsmicznymi,

- możliwość pojawienia się nieuwzględnionych na etapie projektowania obciążeń wyjątkowych tj. instalacja lub zmiana docelowego umiejscowienia ciężkich urządzeń,

- szkodliwy wpływ na konstrukcje innymi obciążeniami wyjątkowymi tj. pożary czy uderzenia od pojazdów mechanicznych,

- fizyczne zużycie obiektów budowlanych wynikające z długotrwałego użytkowania. 


\subsection{Tradycyjne metody wzmocnień}

Do tradycyjnych sposobów wzmocnień żelbetowych elementów zginanych należą metody: zwiększenie ilości zbrojenia głównego rozciąganego lub zastosowanie zbrojenia aktywnego oraz zwiększenie przekroju poprzecznego elementu konstrukcyjnego wskutek zwiększenie ramienia sił wewnętrznych poprzez dobetonowanie:

- fragmentu z dodatkowym zbrojeniem w strefie rozciąganej,

- nadbetonu w strefie ściskanej,

a także zmiana schematu statycznego w celu zmniejszenia zewnętrznego momentu zginającego (URBAN T. 2015).

Podczas projektowania wzmocnień konstrukcji żelbetowych należy pamiętać, że bezpieczeństwo i niezawodność konstrukcji powinny podnieść się o co najmniej $10 \%$ powyżej wartości wymaganych przez obowiązujące normy lub wartości wynikających z analiz teoretycznych. Ponadto wzmocnienie powinno zapewnić wystarczającą trwałość w warunkach dalszej eksploatacji obiektu (RUNKIEWICZ L. 2011).

Niestety zabiegi związane ze wzmocnieniami metodami tradycyjnym często są bardzo pracochłonne na etapie realizacji (odpowiednie przygotowanie podłoża, wieloaspektowa implementacja), wymagają pracy ciężkiego sprzętu, wymuszają zwiększenie wymiarów wzmacnianych elementów konstrukcyjnych (niejednokrotnie niemożliwego do wykonania) oraz konieczność stosowania środków antykorozyjnych (przy technologii wzmocnień stalowych). Spowodowało to pojawienie się potrzeby zastosowania nowych rozwiązań materiałowych, mogących wyeliminować mankamenty tradycyjnych metod. Jednym z rozwiązań jest wzmacnianie elementów konstrukcyjnych za pomocą materiałów kompozytowych (BASZKIEWICZ K., SELEJDAK J. 2015), (KAŁUŻA M., BARTOSIK T. 2015).

\subsection{Wzmocnienia kompozytowe}

Materiały kompozytowe odnajdują swoje zastosowanie w budownictwie od lat 80 . XX wieku. Obecnie metoda wzmacniania 
elementów konstrukcyjnych za pomocą kompozytowych mat oraz taśm (rys. 3) jest powszechnie stosowaną, zwłaszcza w dziedzinie mostownictwa.

a)
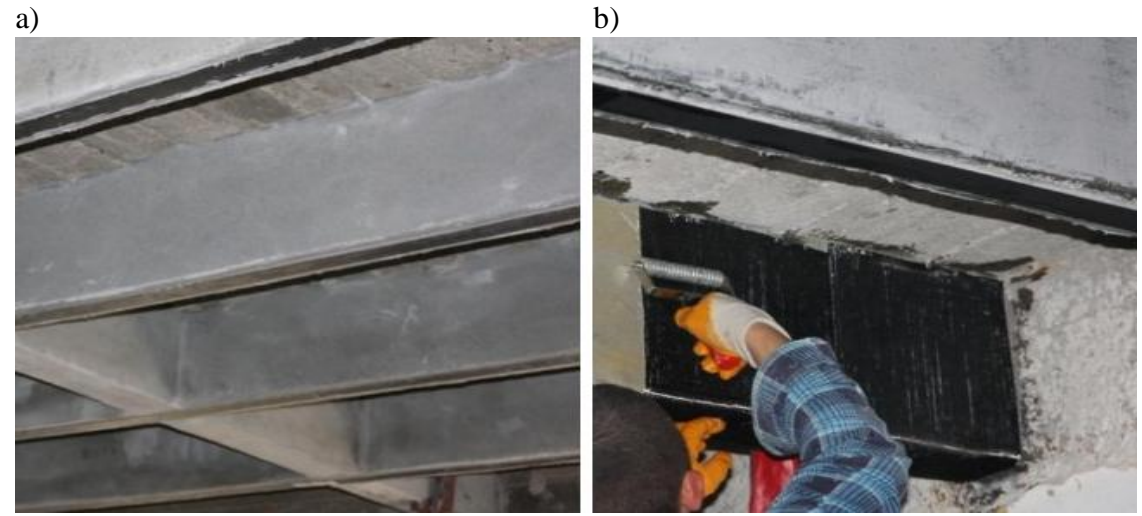

Rys. 3. Wzmacnianie belki żelbetowej za pomoca:

a) taśm z wlókien węglowych, b) mat z wlókien węglowych

Źródto: POGAN K. 2010.

Wzrost popularności tej metody jest związany przede wszystkim ze świetnymi parametrami wytrzymałościowymi materiałów kompozytowych, ale również z łatwością wykonania tegoż wzmocnienia. Przykładowo taśma kompozytowa najczęściej przyklejana jest do powierzchni betonu w strefie rozciąganej przy użyciu kleju, zapewniając tym samym współpracę na powierzchni styku taśmy z betonem. Ponadto z uwagi na relatywnie niewielki ciężar własny taśm podczas aplikacji nie jest konieczne wykorzystanie specjalnego sprzętu, taśmy zaś dostarczane są na budowę w postaci rolek. Na palcu budowy taśmy, oprócz pocięcia ich na odpowiedniej długości odcinki, nie wymagają dodatkowej obróbki wstępnej. Maty kompozytowe również są łatwe w montażu. Przyklejane są na wcześniej wyprofilowaną i zaimpregnowaną powierzchnię betonu za pomocą gumowego wałka. Zewnętrzną powierzchnia mat dodatkowo pokrywana jest warstwą zabezpieczającą, tworzącą bardzo wytrzymałą 
powłokę wzmacniającą, odporną na działanie czynników korozyjnych. Elementy o złożonych kształtach też mogą być wzmacniane za pomocą tej technologii. $\mathrm{W}$ takim przypadku maty kotwione są $\mathrm{w}$ narożach wzmacnianych elementów za pomocą kołków wstrzeliwanych (BASZKIEWICZ K., SELEJDAK J. 2015), (SIWOWSKI T. 2012).

Efektywność wzmocnień żelbetowych elementów konstrukcyjnych tj. przyklejania zewnętrznego zbrojenia w postaci kompozytowych taśm do powierzchni betonu jest potwierdzona wieloma badaniami. Jednakże kompozyty przyklejane w stanie biernym nie umożliwiają pełnego wykorzystania ich wytrzymałości na rozciąganie. Efektywność wykorzystania właściwości wytrzymałościowych kompozytowych taśm jest na poziomie jedynie $40 \%$, a bezpośrednią przyczyną tego wyniku jest utrata przyczepności na połączeniu beton - klej - taśma kompozytowa.

\subsection{Wzmacnianie kompozytami wstępnie sprężonymi}

Celem zwiększenia stopnia efektywności wzmocnienia, opracowano metody wykorzystania taśm kompozytowych w postaci wstępnie sprężonej. Dodatkową korzyścią wynikającą z takiego rozwiązania jest zmniejszenie rozwarcia rys lub całkowite ich domknięcie podczas pracy konstrukcji (BASZKIEWICZ K., SEleJdAK J. 2014), (KotYNia R., STaŚKIEWICZ M. 2013.), (ŁAGODA M. 2012a).

Do metod naprężania materiałów kompozytowych wykorzystywanych do wzmacniania elementów żelbetowych należą m.in. (ŁAGODA M. 2012a), (LAGODA M. 2012b):

- wstępny naciąg taśm za pomocą specjalnego urządzenia kotwiąco sprężającego - zakotwienie sprężonej taśmy poprzez płytę kotwiącą, naciąg taśmy za pomocą bloku oporowego (częściowo usuwanego po sprężeniu i zakotwieniu taśmy),

- zakotwienie końców taśm w głowicy trwale przytwierdzonej do wzmacnianej konstrukcji za pomocą stalowego bloku (konieczność wywiercenia otworu w konstrukcji), 
- $\quad$ system IBDiM - sprężenie taśm za pomocą płaskiego stalowego bloku oporowego (umożliwiającego zakotwienie na stałe naciągniętej taśmy) oraz szczęk naciągowych (usuwanych po naprężeniu i zakotwieniu taśm), usytuowanych w charakterystycznej wnęce wykonanej w strefie zakotwienia każdej taśmy,

- system Neoxe - składający się z biernego i czynnego zakotwienia taśmy (zakotwienie przenosi siłę sprężającą na powierzchnię betonu poprzez skleinę, nity i tarcie) oraz specjalnego układu sprężającego.

Zwiększenie efektywności wzmocnienia betonowego elementu poprzez wykorzystanie technologii wstępnego sprężania kompozytów niesie za sobą korzyści związane z pozytywnym wpływem zarówno na stany graniczne nośności, jak i użytkowalności (m.in. zarysowanie). Sprężone taśmy przenoszą część obciążeń stałych, współdziałają ze wzmocnionym elementem przy przenoszeniu obciążeń zmiennych, a także zmniejszają naprężenia w istniejącym wewnętrznym zbrojeniu (ŁAGODA M. 2012b).

\section{Podsumowanie}

Zapewnienie odpowiedniej trwałości, niezawodności oraz bezpieczeństwa jest sprawą priorytetową podczas projektowania obiektów budowlanych. Celem spełnienia wymogów określonych przez Prawo budowlane oraz stanów granicznych stosowane są zabiegi mające na celu zwiększenie parametrów wytrzymałościowych elementów konstrukcyjnych. Jedną z najpowszechniejszych metod wzmacniania konstrukcji betonowych jest zastosowanie wewnętrznego zbrojenia w postaci prętów stalowych, co pozwala na efektywne wykorzystanie właściwości stali i betonu. Niestety niejednokrotnie wskutek popełnianych błędów związanych z niewłaściwą realizacją lub użytkowaniem, może dojść do przedwczesnego zużycia lub uszkodzenia konstrukcji. Wówczas wykonuje się różnego rodzaju wzmocnienia konstrukcji celem przywrócenia lub zwiększenia nośności tj. zwiększenie ilości zbrojenia lub przekroju poprzecznego przez częściowe dobetonowanie, a także zmianę schematu statycznego. 
Rozwój dziedziny budownictwa i inżynierii materiałowej powoduje wprowadzanie nowych rozwiązań konstrukcyjno - materiałowych mających na celu zwiększenie trwałości i niezawodności obiektów budowlanych. Przykładem jest zastosowanie niemetalicznych prętów kompozytowych jako zbrojenie betonu. Charakteryzują się one dużą odpornością na czynniki powodujące korozję oraz wysokim stosunkiem wytrzymałości do ciężaru własnego. Oprócz tego, w celu eliminacji mankamentów tradycyjnych metod, do wzmacniania istniejących obiektów również wykorzystywane są dużo bardziej trwałe i łatwiejsze w montażu materiały kompozytowe (taśmy, maty). Ponadto stosowane są techniki mające na celu zwiększenie efektywności takiego wzmocnienia poprzez wstępne sprężanie kompozytu, co niesie za sobą szereg korzyści związanych z pozytywnym wpływem na warunki stanów granicznych nośności i użytkowalności.

\section{LITERATURA:}

1. AJdukiewicz A., Mames J. 2004. Konstrukcje z betonu sprężonego. Polski Cement, Kraków.

2. BASZKIEWICZ K., SELEJDAK J. 2014. Comparison of selected properties of reinforced concrete and prestressed concrete structures for bending structural components. Rozdział 14. W: Toyotarity. Management of technology. Aeternitas. Borkowski S., Ingaldi M. (red.) Publishing House. Alba Iulia.

3. BASZKIEWICZ K., SeleJdAK J. 2015. Zastosowanie wybranych materiatów kompozytowych $w$ konstrukcjach mostowych. Rozdział 35. W: Wybrane interdyscyplinarne zagadnienia budownictwa. Nagórski R. (red.) Oficyna Wydawnicza Politechniki Warszawskiej. Warszawa.

4. KAlUŻA M., BARTOSIK T. 2015. Wzmacnianie konstrukcji budowlanych materiałami kompozytowymi FRP. „Inżynier Budownictwa” (4)2015.

5. KotyNia R., STAŚKIEWICZ M. 2013. Analiza efektywności wzmocnień żelbetowych elementów zginanych za pomoca wstępnie naprężonych kompozytów CFRP. „Budownictwo i Architektura” 12(1).

6. ŁAGODA M. 2012a. Wzmacnianie konstrukcji mostowych kompozytami wstępnie sprężonymi, cz.1. „Nowoczesne Budownictwo Inżynieryjne” 3(42). 
7. ŁAGODA M. 2012b. Wzmacnianie konstrukcji mostowych kompozytami wstępnie sprężonymi, cz.2. „Nowoczesne Budownictwo Inżynieryjne” 4(42).

8. MAdAJ A., WOlowsKi W. 2002. Mosty betonowe. Wydawnictwo komunikacji

i łączności sp. z o.o. Warszawa.

9. PoGAN K. 2010. Wzmacnianie konstrukcji kompozytami FRP wedtug MAPEI.

Dostępne:

http://www.chemiabudowlana.info/index,art,2450,index_czytelnia, wzmacnianie_konstrukcji_kompozytami_frp_wedlug_mapei z dnia: 12.12.2015

10. RUNKIEWICZ L. 1999. Diagnostyka $i$ wzmacnianie konstrukcji żelbetonowych. Wydawnictwo Politechniki Świętokrzyskiej. Kielce.

11. RUNKIEWICZ L. 2011. Wzmacnianie konstrukcji żelbetowych. Instytut Techniki Budowlanej. Warszawa.

12. SELEJDAK J., BRÓZDA K. 2016. Zastosowanie kompozytów w budownictwie zrównoważonym. Rozdział 9. W: Zagadnienia inżynierii środowiska w budownictwie. Rak A., Boychuka V., Baran W. (red.) Polski Związek Inżynierów i Techników Budownictwa, Oddział w Opolu. Opole.

13. SIWOWSKI T. 2012. Materiaty kompozytowe CFRP stosowane we wzmacnianiu mostów betonowych. Mosty 4/2012.

14. URBAN T. 2015. Wzmacnianie konstrukcji żelbetowych metodami tradycyjnymi. Wydawnictwo Naukowe PWN. Warszawa.

15. MATERIAŁY PROMOCYJNE DOSTĘPNE NA: http://polprek.pl/ z dn. 03.01.2016 